\title{
What is the Most Potential Coastal and Marine Resources in the Buleleng Region?
}

\author{
I Putu Sriartha ${ }^{1}$, I Gede Astra Wesnawa ${ }^{2}$, Ida Bagus Made Astawa ${ }^{2}$ \\ I Putu Ananda Citra ${ }^{4}$, Putu Indra Christiawan ${ }^{5}$, I Made Sarmita ${ }^{6}$, A. Sediyo Adi Nugraha ${ }^{7}$ \\ \{putu.sriartha@undiksha.ac.id ${ }^{1}$, astra.wesnawa@undiksha.ac.id², md.astawa@undiksha.ac.id ${ }^{3}$ \} \\ Universitas Pendidikan Ganesha, Indonesia ${ }^{1234567}$
}

\begin{abstract}
This study aimed to map the existing conditions of coastal and marine resources owned by the Buleleng Regency. The method used to achieve this goal is to use remote sensing methods to measure coastal resources scattered in the coastal area of the Buleleng Regency, which is then analyzed qualitatively. The results showed that coral reefs were the most potential coastal and marine resources in the Buleleng area based on their square area. The study also found that coastal and marine resources are mostly scattered in Buleleng's western sector. This fact has implications for the orientation towards the development of coastal areas in the Buleleng Regency.
\end{abstract}

Keywords: Coastal and marine; Resource; Potency; Spatial Distribution; Coastal Areas

\section{Introduction}

Indonesia is an archipelago with 17,508 islands and a coastline of $81,000 \mathrm{~km}$ and a sea area of about 3.1 million $\mathrm{km} 2$. Indonesia's coastal areas, which have enormous wealth, must be preserved by utilizing regional functions in a planned, harmonious, balanced, and responsible manner by paying attention to environmental sustainability aspects to improve people's welfare [1], [2]. The marine sector always deals with the coastal sector because the coastal and marine sectors are two things that cannot be separated. In simple terms, the coastal area is the meeting point between land and sea, with a land boundary covering parts of the land, both dry and submerged in water, which are still affected by marine characteristics, such as sea breezes, tides, seawater seepage [3]. The role of the coast as a regulator of environmental balance, climate balance, and geothermal balance. Coastal resources are a tremendous and promising asset in the future. The utilization of coastal resources in each region has increased, but coastal resources management is still far from optimal and sustainable. One of the coastal potentials, which is the main potential that must be mapped, is coral reefs. The condition of coral reefs is an indicator of the condition of coastal fisheries. Coral reefs have a significant meaning because of their function and role both ecologically, socially, and economically for other biota and the lives of people living in coastal areas [4]. Managing coastal resources in an integrated manner with the initial step, namely mapping the coast's potential, is the early step to optimizing the resources.

This provision has been explicitly stipulated in the law on coastal resource management that is directed at utilizing the existing potential for the achievement of welfare and improving coastal communities. This should be a vital asset for equitable development. However, what is 
happening now is the imbalance of development, especially in the tourism sector, which tends to focus on the South Bali area compared to other areas such as North Bali (Buleleng Regency), East Bali (Bangli Regency and Karangasem Regency), and West Bali (Jembrana Regency). People in South Bali can already feel the benefits of the tourism sector and its associated sectors, but the opposite condition occurs in North Bali, East Bali, and South Bali. The impact of this condition is the occurrence of economic inequality by the people in each region.

The rapid development of the region, especially the tourism sector in southern Bali, such as Kuta Beach and Sanur to the Ubud Gianyar area, does not occur in other districts such as Buleleng Regency. At the same time, Buleleng Regency has the longest beach in Bali, which is $157.05 \mathrm{Km}$ and has the largest area than other Bali. This means that the potential that is owned, especially the potential for coastal resources, is enormous to be developed. Great potential without planning will not get maximum results. Regional planning is the first step in developing potential. Therefore, this research's main objective is to map the potential of coastal and marine resources in the Buleleng region.

\section{Method}

The research design used to achieve the research objectives is the remote sensing method. The distribution of coastal and marine resources will be easily mapped through remote sensing image data and know their extent.The object of research is the potential of coastal resources in the Buleleng Regency. Based on the research object, the research subject is the coastal area of the Buleleng Regency. Based on the research subject, the research population is the Buleleng Regency coastal area. The coastal area of the Buleleng Regency is all villages that are administratively included in Buleleng Regency. Determining the sample for this research activity using a purposive sampling technique, namely by considering the coastal area, is limited by the village administration area.

Data collection in this study consisted of several stages. The first step is to download the data. The satellite imagery used is medium resolution, namely the Landsat 8 OLI/TIRS image, obtained free of charge on the USGS official website, http://usgs.gov/. In addition, the use of vector data is obtained for free on the official website of the Badan Informasi Geospasial (BIG), namely http://tanahair.indonesia.go.id/. Furthermore, data on the potential area of coastal areas is obtained by digitizing, which is thought to have potential in coastal areas. Finally, documentation proves the results of remote sensing image data processing in the field and presented in the form of photographs. The data that has been collected is analyzed qualitatively by limiting the potential of the coastal area based on the smallest unit, whether it is a hamlet or the potential location boundary itself, based on physiographic conditions through Landsat 8 OLI/TIRS imagery. The location of the spatial distribution of coastal resources owned by the Buleleng region will be obtained through this.

\section{Result and Discussion}

Coastal and marine resources can also be classified into renewable resources and nonrenewable resources. Coastal resources that include renewable sources include mangrove forests, coral reefs, seagrass beds and seaweeds, marine fisheries resources, and bioactive 
materials. Meanwhile, resources that cannot be recovered consist of all minerals and geology, one of which is sand. The distribution of potential coastal resources in the Buleleng area is shown in Table 1.

Table 1. Spatial Distribution of Coastal and Marine Resources Potentials in Buleleng Area

\begin{tabular}{|c|c|c|c|c|c|c|c|c|c|c|}
\hline \multirow{3}{*}{$\begin{array}{l}\text { Buleleng } \\
\text { Region }\end{array}$} & \multicolumn{8}{|c|}{ Resource Area (Hectares) } & \multicolumn{2}{|c|}{ Total } \\
\hline & \multicolumn{2}{|c|}{ Coral Reefs } & \multicolumn{2}{|c|}{ Mangrove } & \multicolumn{2}{|c|}{ Sands } & \multicolumn{2}{|c|}{ Ponds } & & \\
\hline & $\mathrm{N}$ & $\%$ & $\mathrm{~N}$ & $\%$ & $\mathrm{~N}$ & $\%$ & $\mathrm{~N}$ & $\%$ & $\overline{\mathrm{N}}$ & $\%$ \\
\hline West Sector & 719,4 & 79,5 & 244,1 & 100 & 0 & 0,0 & 199,1 & 86,2 & 1162,7 & 81,5 \\
\hline Middle Sector & 185,3 & 20,5 & 0 & 0,0 & 30,1 & 64,0 & 20,3 & 8,8 & 235,6 & 16,5 \\
\hline East Sector & 0 & 0,0 & 0 & 0,0 & 16,9 & 36,0 & 11,7 & 5,1 & 28,6 & 2,0 \\
\hline & 904,7 & 100 & 244,1 & 100 & 47 & 100 & 231,1 & 100 & 1426,9 & 100 \\
\hline
\end{tabular}

Table 1 shows the area of the four most considerable coastal and marine resources in the Buleleng region, as measured by their square area. Overall, the Buleleng area, with the most coastal and marine resources, is the west sector with 1162.7 ha or $81.5 \%$ of the resource's total area. Meanwhile, the most extensive coastal resources owned by the Buleleng area are biological resources in coral reefs covering an area of 904.7 ha.

Coral reef ecosystems are typical ecosystems of tropical coastal waters, which are formed from massive deposits of Calcium Carbonate $\left(\mathrm{CaCO}_{3}\right)$ produced by hermatypic coral organisms (Phylum Cnidaria) such as Acropora, Fungia, and Porites, which are symbiotic with Zooxanthellae [5]. Research by Andronicus et al. [6] proves that coral reefs are a very significant barrier to natural waves, especially fringing corals and atoll corals. Besides that, coral reefs are also a habitat for fish, both ornamental and fish for public consumption [7], and coral reefs can also function as beautiful marine tourism objects [8]. The most coral reefs are spread in the West sector with 719.4 ha or $61.9 \%$ and followed by the middle sector with an area of 185.3 ha $(20.5 \%)$. Despite being the most extensive biological resource, not all areas of Buleleng have coral reefs. The East sector is a Buleleng area that has no coral reef resources. Thus, coral reefs can become a major icon for developing coastal areas in Buleleng Regency, especially in the west sector.

Mangroves are coastal resources that have various functions, including socio-economic functions, ecological functions, and physical functions. Mangrove forests are a source of life and food for various living things, such as shrimp, crabs, birds, fish, and mollusks [9]. The mangrove forest is a general term used to describe a tropical coastal community dominated by several unique tree species or shrubs that can grow in salty waters [10]. Many studies have proven the benefits of mangroves in coastal areas. Research by Fatimatuzzahroh et al. (2018) shows the dual benefits of mangroves: mangroves are used to overcome abrasion problems and can then be used as development in tourism areas. In the use of ecosystems, Mukhlisi \& Purnaweni [12] explained that the mangrove area plays a role in living for Rhizoporara species, even though the area is not too large. Mangroves occupy the second position of the most massive coastal resources in the Buleleng area, with an area of 244.1 ha. Mangrove resources are endemic resources that are only scattered in the west sector. Thus, the western part of Buleleng has a vast potential to become a center for mangrove forest development.

Ponds are the third largest coastal resource, with a total area of 231.1 ha. Ponds is a coastal resource that is scattered throughout the Buleleng area. Ponds are mostly spread in the 
west sector with a percentage of $86.2 \%$, followed by the middle sector $(8.8 \%)$ and the east sector $(5.1 \%)$. The difference in ponds between the western and other sectors is due to differences in land potential, including differences in soil types and topographic conditions. Research Setianingrum et al. (2014) explains that ecological changes in the pond environment affect pond production. Utojo \& Ratnawati (2013) identified the requirements for ponds' locations in coastal areas, including having a tidal height of 1.1-2.1 m. The beach topography is relatively sloping with a rather deep seabed, and rainfall is less than $2,000 \mathrm{~mm} / \mathrm{year}$, free from flooding, protected from the influence of strong currents, big waves, strong winds, and free of contamination.

Finally, the coastal resource with the smallest area is sand, with 47 ha. Sand resources are only found in the middle and east sectors. The distribution of sand resources is more in the middle sector (64\%) than in the east sector $(36 \%)$. Sand is a mining material that has economic value. Currently, the exploitation of sand in coastal areas occurs in quite a large number. The immense potential for sand is to meet the demand for backfilled sand and meet the demand for sand to open new land to the coastal area [15].

Tourism is one of the potential coastal areas that can contribute to coastal areas in the Buleleng Regency. Apart from having an economic impact, tourism also has a significant ecological impact on the improvement and sanitation of the surrounding environment [16], [17]. Through coastal tourism development programs for the beach's beauty, panorama or the development of mangrove forests is one of the tourism potentials that are synergized with the development of conservation of coastal and marine resources.

\section{Conclusion}

Coral reefs, mangroves, ponds, and sand are the four primary coastal and marine resources in the Buleleng area. Based on land cover, coral reefs are the most potential coastal and marine resources to be developed, especially in the western part of Buleleng. Coral reefs have great potential to become habitat and source of food for various types of marine life so that this area will become the natural guardian of biodiversity, and at the same time, become the most massive marine tourism owned by Buleleng Region. Another interesting finding is that, although it does not have biological resources, the eastern Buleleng region has great potential in developing ponds, especially salt ponds. The application of a coastal area management strategy based on the specificity of the resource's potential becomes a strong foundation for sustainable coastal development.

\section{References}

[1] D. Marliana, Sarwono, and M. Rozikin, "Coastal Area Management Policies Based on Sustainable Development in Sampang Regency (Study at the Development Planning Department Sampang Regency) (in Bahasa)," J. Adm. Publik, vol. 1, no. 3, pp. 80-86, 2017.

[2] I. G. A. Wesnawa, P. I. Christiawan, N. L. G. E. Sulindawati, and N. A. W. T. Dewi, "Enhancing science and technology through coastal damage management model," J. Adv. Res. Dyn. Control Syst., vol. 11, no. 5, pp. 373-378, 2019.

[3] L. Sara, Coastal Zone Management (in Bahasa). Jakarta: Penerbit Alfabeta, 2014.

[4] N. N. Yulius, A. Taslim, L. Hadiwijaya, R. M. Salim, and D. Purbani, "Spatial Distribution of Coral Reefs in the Waters of Wangi-Wangi Island, Wakatobi (in Bahasa)," J. Ilmu dan Teknol. Kelaut. Trop., vol. 7, no. 1, pp. 59-69, 2015. 
[5] T. R. McClanahan, "The near future of coral reefs," Environ. Conserv., vol. 29, no. 4, pp. 460483, 2002.

[6] Andronicus, F. Yulianda, and A. Fahrudin, "Study of the Sustainability of Marine Protected Area-Based Ecotourism Management (DPL) on the Coast of Bahoi Village, North Minahasa, North Sulawesi (in Bahasa)," Jemis, vol. 4, no. 1, pp. 1-10, 2016.

[7] A. Arisandi, B. Tamam, and A. Fauzan, "Coral reef profile of Kangean Island, Sumenep District, Indonesia,” J. Ilm. Perikan. Dan Kelaut., vol. 10, no. 2, pp. 76-83, 2018.

[8] D. N. Wijaya, Suryanti, and Supriharyono, "Suitability of coral reef ecosystems for ecotourism as diving activity on Kayu Angin Genteng, Seribu Islands," Diponegoro J. Maquares, vol. 4, no. 4, pp. 109-118, 2015.

[9] M. Indrayanti, A. Fahrudin, and I. Setyobudiandi, "Assessment of Mangrove Ecosystem Services in Blanakan Bay, Subang Regency (in Bahasa)," J. Ilmu Pertan. Indones., vol. 20, no. 1, pp. 91-96, 2015.

[10] S. Faturrohmah and B. Marjuki, "Identification of the Spatial Dynamics of Mangrove Resources in the Coastal Area of Demak Regency, Central Java (in Bahasa)," Maj. Geogr. Indones., vol. 31, no. 1, pp. 1-10, 2017.

[11] F. Fatimatuzzahroh, S. P. Hadi, and H. Purnaweni, "Mangrove cultivation community based in Karangsong, Indramayu, West Java," IOP Conf. Ser. Earth Environ. Sci., vol. 145, no. 1, p. 012139, 2018.

[12] Mukhlisi and H. Purnaweni, "The Diversity of Types and Structures of Mangrove Vegetation in Sidodadi Village, Padang Cermin District, Pesawaran Regency, Lampung Province (in Bahasa)," 2013.

[13] D. R. Setianingrum, A. Suprayogi, and Hani'ah, "Analysis of Pond Land Suitability Using a Geographic Information System (Case Study: Brangsong District, Kendal Regency, Central Java Province) (in Bahasa)," J. Geod. Undip, vol. 3, no. 2, pp. 69-80, 2014.

[14] Utojo and E. Ratnawati, "Study of the Suitability of Pond Cultivation Land in the Coastal Area of Pangkep Regency, South Sulawesi with a Geographic Information System Application (in Bahasa)," J. Ris. Akuakultur, vol. 8, no. 3, pp. 479-491, 2013.

[15] W. Wahyudi, E. Riani, and S. Anwar, "Strategy of sustainable sea-sand mining (A case study in Tunda Island, Banten)," J. Ilmu dan Teknol. Kelaut. Trop., vol. 10, no. 2, pp. 277-289, 2018.

[16] D. Apriana and D. Milla, "Potential Utilization of the Coastal Ecosystem of Labuhan Haji, East Lombok as an Ecotourism Area (in Bahasa)," J. Biol. Trop., vol. 17, no. 1, pp. 15-22, 2017.

[17] P. Bjork, "Ecotourism from a conceptual perspective, an extended definition of a unique tourism form," Int. J. Tour. Res., vol. 2, no. 1, pp. 189-202, 2000. 